\title{
The Role Of Due Diligence In The Business Valuation Process
}

Terry Mullins, (E-mail: tmullin@ju.edu), Jacksonville University

Barry Thornton, (E-mail: bthornt@ju.edu), Jacksonville University

Michael Adams, Jacksonville University

\begin{abstract}
The due diligence process enables investors to do a better job of determining the appropriate price to pay for a privately held firm. This article delineates some factors that a prospective buyer should investigate thoroughly to determine the value of a small, privately held business under consideration for purchase.
\end{abstract}

\section{ACQUISITION OF SMALL, PRIVATE FIRMS}

\section{Advantages Of Buying A Business}

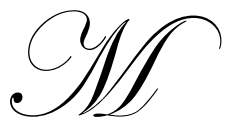

uch attention, both scholarly and practical, has been focused on the business formation process. This attention is understandable because starting a new business is emotionally engaging as well as vital to the health of the economy. Comparatively little attention, however, has been given to the dynamics of buying established, privately held businesses.

Buying an established business is less risky than starting one from scratch. When one buys a going concern, the founder has already solved many of the most critical problems. After all, the founder selected a location, obtained the necessary licenses, created relationships with suppliers, established an accounting system, hired employees and attracted customers. By getting the business up and running, the founder made, paid for and learned from the most costly start-up mistakes (Fraser, 1996). The buyer benefits from the start-up efforts of the founder, and those benefits usually outweigh the purchase price. An on-going business has tested the viability of the firm's business model, the wisdom of its strategy, the effectiveness of its marketing and the power of its advertising.

The acquisition process is not without its problems, however. Both the buyer and the seller may be troubled about the wisdom of their decisions when the ownership of a business changes. The seller may fret that the buyer will not be able to pay for the business, a particularly pertinent concern if the seller provides financing to the buyer. A founder, who may have spent years building a positive business image, may fear for the firm's future reputation. In addition, a seller may worry about the welfare of his or her former employees.

The buyer also has concerns. Will he or she have the expertise to run the business successfully? Will the business generate enough cash flow to survive, let alone thrive? Will the business perform as well as the seller has promised or the buyer has been led to believe? What undisclosed problems or liabilities threaten the business's future? Do the financial statements present an accurate picture of the firm's condition?

An often-overlooked advantage of buying an established business is the assistance the seller may provide after the sale. The seller may stay with the firm for a time after the sale to advise the new owner about transitional issues. A seller may frequently play a key role in creating positive relationships with the firm's employees, customers, suppliers and lenders. 


\section{Components Of The Asking Price}

Usually, the buyer and seller will not agree initially on a selling price for the business, nor will they use the same methods for valuing the worth of the firm. The seller is often inclined to overvalue the business, giving undue weight to personal or emotional needs. The buyer, on the other hand, is likely to undervalue the business, influenced primarily by the amount of cash and financing available for the purchase. A more objective approach to valuation would examine both past and pro forma cash flows to determine the worth of the business. Factors such as real estate, patents and trade secrets owned by the business may increase the selling price, while other factors such as outstanding lawsuits, changes in the regulatory environment and impending managerial changes may decrease it.

To consummate a sale, the buyer and seller may need to adjust their initial estimates of the worth of the business. The process of due diligence helps the buyer and seller arrive at a mutually acceptable price for the business. While the due diligence process is usually approached as a way to test the veracity of the seller's representations, it can also serve to educate the buyer and the seller about the true worth of the business. (Preston, 2005)

\section{The Importance Of The Due Diligence Process}

The prudent investor understands the advantages of buying an established business, but also recognizes the pitfalls awaiting the unwary purchaser. The cautious buyer reduces acquisition risks by engaging in thorough due diligence before finalizing the purchase. While some buyers skip due diligence, considering it an unnecessary expense, such a decision is usually unwise. A systematic due diligence can prevent a financial calamity or allow the purchase of the target firm for a better price or on more advantageous terms.

The responsibilities of a due diligence analyst include verifying the accuracy of the seller's representations, discovering undisclosed problems, and uncovering hidden assets and opportunities. If due diligence verifies the accuracy of the seller's representations, the buyer's confidence in the original valuation increases. Similarly, the discovery of hidden or neglected assets automatically increases the value of the deal for the purchaser. On the other hand, when due diligence reveals undisclosed problems, the buyer has an opportunity to walk away from the deal or negotiate a more favorable purchase price. In each of these cases, due diligence significantly enhances the buyer's position in the potential transaction.

\section{CONDUCTING DUE DILIGENCE}

The buyer conducts due diligence to make certain that he or she understands fully all aspects of the business that is for sale. A serious due diligence process requires careful planning, the retention of various experts and skillful execution. At a minimum, due diligence needs to be carried out in the following areas: financial statement analysis, inventory, payroll, pension funding, market position, customer and vendor relationships, human resources, legal liabilities, creditor relationships, and intangible assets.

\section{Financial Statements}

The firm's financial statements typically provide critical information about the financial health of the business; however, the accuracy of the picture provided depends on whether or not the accounting records were maintained in accordance with Generally Accepted Accounting Principles (GAAP). If a certified public accountant audited and certified the financial statements, the picture painted by them is probably accurate. Moreover, it is even better if one of the national accounting firms conducted the audit (Dahl, 2004). However, the financial statements of most privately held firms do not meet these criteria. Small, private firms are frequently somewhat casual in their accounting practices. In such cases, due diligence is crucial to determine the value of a business.

The first step in examining the financial statements is to determine how carefully and how long the firm has maintained its accounting records and observed GAAP. The less rigorously GAAP have been applied, the greater effort will be required to verify the accuracy of the financial statements. The precision of the numbers associated with sales, inventory, payroll, travel and business entertainment deserve particular scrutiny. 
Payroll

The payroll costs of many small, private businesses require close inspection. The salary and perquisites of the seller may be considerably higher than they would be for a comparable professional manager. If the current owner is overcompensated, the business may be worth significantly more on a discounted cash flow basis than current financial statements suggest.

When examining payroll issues, the due diligence analyst needs to determine the expectations concerning any future employment at the firm by the seller and his or her family members. Since family members may be overcompensated, there could be an opportunity to increase cash flow upon sale of the business. Conversely, the wages of non-family members currently employed by the firm may be artificially low, causing dissatisfaction and increasing turnover costs.

\section{Inventory}

For many businesses, especially retailers, inventory represents a significant asset. The person responsible for due diligence needs to verify the existence of the inventory and evaluate its salability. Since inventory frequently changes, due diligence in this area presents a challenge. The initial step is to determine if the amount of inventory is comparable to the amount shown on the books. If not, the analyst needs to establish if the difference is due to ordinary fluctuations or if there is a systematic misrepresentation. The second step consists of determining if the inventory is salable, which can be particularly difficult for fashion-oriented businesses such as apparel or in technology, where obsolescence is an issue.

\section{Pension Funding}

The due diligence effort should include an assessment of the company employee pension fund to determine whether it is over funded or under funded. Under funding could result in a significant unrecorded liability, while conversely an over-funded pension plan could result in significant added value to the acquiring firm (Power, 2005). A plan is fully funded when, according to the actuarial standards prescribed, the cumulative contributions to the pension fund are equal to the cumulative payments expected to employees. Publicly traded companies are required to disclose under-funding in the main body of the financial statements, however privately-held companies do not have to meet the same standards. The key assumptions about future implicit growth rates in the investment portfolio may be ripe for exploration. If the company uses a defined contribution plan, however, a different set of analyses would be in order.

\section{Travel and Entertainment Expenses}

Many travel and entertainment expenses may not be strictly necessary for the success of the business. Small, private firms frequently provide luxury cars to the owner(s) and family members. Some owners regularly charge travel, meals and entertainment that may have both business and personal objectives. A thorough investigation should show whether the owner(s) and family members might have misused the travel and entertainment account. If so, the analyst has discovered additional cash flow that increases the value of the business.

Intangible Assets

Patents, trademarks, service marks, brand names, copyrights, trade secrets, other intellectual property and the reputation of the firm represent intangible assets that may not be readily apparent to the current owner (Fernandez, 2003; Rivas, 2002; Tabon, 2002). Some assets, such as the brand name of the company's major product and patents on manufacturing processes, are currently creating economic value for the firm. However, some intangible assets, such as a brand name of a discontinued product or the backlist of a publisher, may not be a source of current value to the firm, but have the potential to generate significant economic value in the future. In such cases, the business may be worth considerably more than a discounted cash flow analysis would suggest. 
In some cases, a rigorous analysis of the intangible assets of a firm can yield a great opportunity to discover hidden shareholder value. However, naïve optimism in estimating the potential cash flow could result in an erosion of shareholder value. In conducting due diligence, intangible assets should be separated into two general asset categories.

The due diligence effort should attempt to recognize and quantify intangible assets that arise from both a contractual or other legal right(s) and non-contractual but separable basis. (FASB 141) Contractual or separable intangible operating assets would generally include the following: (1) key customer contracts; (2) existing order backlog; (3) operating and financial leases; (4) licensing and royalty agreements; (5) key employee employment contracts; (6) trademarks; (7) web site co-branding agreements; and (8) pollution abatement credits.

Intangible assets that are capable of being split off from the acquired firm and later sold, transferred, rented or exchanged should also be recognized (FASB 142). These non-contractual but separable intangible assets include such diverse items as "grandfathered" exemptions from current regulations, any proprietary, unpatented technologies, registered domain names, trade secrets or prestigious quality awards and certifications. However, any costs associated with the exploitation of these intangible assets should also be included as a reduction in the pro forma cash flow.

\section{Facilities And Equipment}

For manufacturing organizations, facilities and equipment represent a significant proportion of the firm's assets. Facilities obviously include buildings and land owned by the business, but the individual performing the due diligence analysis will need to examine and evaluate other long-term assets as well. The buildings and land owned by a business may represent hidden value if they have higher and better uses. Vacant land and other real estate not needed for immediate business purposes represent assets available for liquidation after the acquisition is complete. In all likelihood, the firm will record this real estate and similar assets on the balance sheet at a cost that is usually less than current market value.

The firm may not employ current facilities optimally. If they are operating below capacity, the acquiring firm may reap a benefit if sales increase. However, if production is at full capacity, the acquiring firm may incur additional costs to accommodate any increase in sales volume. Leased facilities should be examined for suitability and terms. For leases scheduled to expire soon, the analyst needs to determine the conditions under which the lease will be renewed and any renewal options. A particular concern is whether the firm is committed to any long-term leases on closed, unprofitable, or poorly located facilities.

Ideally, the firm's equipment will be functional, up to date, and in good operating condition. The prospective buyer, or an expert retained for this purpose, should attempt to determine the remaining useful economic life of the equipment. For larger companies, this analyst should verify whether the company has a preventative maintenance program or service contracts with manufacturers. If the firm has unused equipment, the resale or salvage value must be established. When the analyst discovers obsolete, malfunctioning, worn out or damaged equipment, he or she should make an estimate of replacement costs.

\section{Customer Relationships}

The market position of the firm can be a significant factor in comparing risks for companies, whether public or private. Small market share, weak brand awareness, and limited influence with suppliers can lower the value of a firm. Similarly, restricted access to the capital markets, dependence on one or two key people, and a litany of other issues associated with size generally contribute to the greater risk associated with privately held companies by potential investors. This increased risk should be reflected in a lower multiple afforded to operating earnings, earnings before interest, taxes, depreciation, and amortization, or cash flows of private firms vis-à-vis publicly traded firms.

Businesses guard their customer lists carefully and are generally coy about the number of their customers, the volume of business per customer, the turnover of customers and loyalty of customers. However, any thorough due diligence process will look deeper into these issues. In a service business, the customer list and customer loyalty 
represent the primary value of the firm. Frequently, the only asset of real interest is the customer list, with an internet service provider representing one of the extreme cases.

The due diligence effort should reveal the strength and size of the customer base. The analyst should ascertain the firm's effectiveness in attracting and retaining customers. If the business extends credit to customers, the analyst will want to know about the payment history and financial strength of the customer base. Of particular interest will be the financial stability of the firm's largest customer.

Additionally, the due diligence analyst will be particularly eager to learn of any impending defections of major customers. The acquiring firm needs to know if customers' loyalty lies with the company or with the owner. In this regard, the analyst should find out about the owner's plans regarding starting a new business or working for a competitor. If immediate competition from the seller is likely, the buyer should insist on a non-complete clause in the purchase agreement.

\section{Vendor Relationships}

In certain cases, vendor relationships can be almost as important as customer relationships. Before purchasing a business, the acquiring firm needs to discover how well key vendors have been performing in terms of on-time delivery, product quality, return policies and willingness to resolve problems. Since a financially weak vendor has the potential to cause serious problems for a company, the due diligence analyst should conduct a financial analysis of important vendors (Goldman, 2005; Oakes, 2004).

According to Fulton (2003), other factors to explore include the vendor's willingness to provide favorable prices, convenient delivery schedules and generous payment terms. Furthermore, will the sale of the firm cause vendors to renegotiate contracts or quit supplying the firm?

\section{Management Systems And Human Resources}

Before purchasing a business, the acquiring company needs to determine the strength of the target firm's management team, as well as its management systems. As Melles observed (1996), evaluating the firm's employees during due diligence can be a delicate matter. For example, if the analyst is too aggressive in appraising the capabilities of the firm's management team and other employees, morale and productivity may suffer.

Nepotism

Even in the best of circumstances, assessing current employees is challenging and may not always be feasible. However, significant nepotism, which is usually not difficult to discover, raises a red flag concerning the quality of all employees. If family members hold all essential management positions, the overall competence of the management team should be brought into question. In cases of extreme nepotism, competent, ambitious employees who are not relatives are unlikely to stay with the firm. After the purchase, the acquiring firm may realize significant performance improvements by terminating the less competent family members. The elimination of nepotism should result in improved motivation of current employees, and make it possible to attract better employees in the future.

\section{Depth of management}

Privately held firms are frequently dependent upon a key leader, who often has personal relationships with customers, strong ties with suppliers and typically oversees operations. As Greengard (1999) noted, the loss of such a person after the purchase could jeopardize the associations with existing customers, suppliers and creditors. If a bank loaned the firm money on the strength of the owner's vision and integrity, perhaps even requiring his personal guarantee, the departure of the owner may threaten the credit position of the firm. This is in stark contrast to the typical public company where there is a usually strong management team with greater size, depth, and capabilities.

Moreover, the typical publicly traded firm generally has a stronger equity base to weather any transition. More often than not, to attract debt financing, a private company must look to banks that frequently demand higher 
interest rates, require more restrictive loan covenants, and expedited amortization of loans. Furthermore, debt terms are often less advantageous for rapidly growing small firms requiring regular infusions of working capital. When privately held companies employ "asset based" financing, cash advances on the resulting line of credit is typically at $2-6 \%$ above prime.

Managerial Systems

Small, private firms seldom possess strong management systems. A firm run by its founder often retains an informal, "by-the-seat-of-the-pants" style far longer than its professionally managed counterpart does. As a starting point, the due diligence analyst should ascertain if an employee handbook or manual exists. If there is such a manual, it should be evaluated to determine if it is complete, clearly written, internally consistent and in compliance with employment, health and safety laws and regulations.

The analyst should verify whether the company has systematic, written procedures for the hiring, orientation, training, compensation, appraisal and promotion of personnel. Since most small firms lack such written documents, it is a positive sign if documentation exists. Even more impressive is if the firm actually follows its formal, written procedures. Given the complexity of these issues, the acquiring firm should have these documents examined by an attorney who specializes in employment law (Greengard, 1999; Kessenides, 2004).

\section{Potential Legal Liabilities}

One of the most important tasks of the due diligence analyst is to uncover any potential legal liabilities confronting the firm. Initially, the acquiring firm needs to ascertain if there is any outstanding or upcoming litigation facing the target firm. While the analyst can readily find extant lawsuits in the public record, discovering potential lawsuits will require more investigation (Kessenides, 2004; Pallarito, 1995). If the firm to be purchased is a manufacturer that used or uses chemicals extensively, the analyst should explore the possibility of a potential hazardous waste liability. Similarly, the analyst should determine whether current or former employees have been exposed to asbestos, mercury, benzenes or other hazardous materials (Bennett and Bowles, 1994).

\section{A FURTHER CONSIDERATION}

In the case of a business combination or consolidation, careful due diligence requires that any synergies be identified and quantified. Synergies are the projected increases in competitiveness and cash flows resulting from the merger of two businesses over and above what the two separate businesses could accomplish independently. Proper due diligence is required to determinate the economic values for the synergies as well as the front-end costs of integrating the two businesses less any negative synergies that might occur (e.g. customer base overlap).

Synergistic benefits typically fall into two broad categories. The first category consists of increased cash inflows or revenue gains that are expected to result from the combined firm's ability to cross-sell products or services, better leveraging of sales channels and marketing programs, higher selling prices or other similar competitive advantages. The second category of benefits is reduced cash outflows resulting from economies of scale, reduction in capital expenditures, production efficiencies, elimination of duplicate costs in areas such as R\&D, volume discounts and other efficiencies that result from a larger or better-focused business.

\section{SUMMARY}

Purchasing a small, privately held business can be more risky than buying a large, publicly traded firm. In particular, it may be more difficult to establish the appropriate offer price for a small firm, for a variety of reasons. The buyer can overcome the uncertainties associated with the valuation of a small firm by conducting a systematic due diligence process. This article delineates some factors that a prospective buyer should investigate thoroughly to determine the value of a small, privately held business under consideration for purchase. 


\section{REFERENCES}

1. _ _ Why Too Many Mergers Miss the Mark, Economist, January 4, 1997, 57 - 58.

2. _. New Accounting for Business Combinations, Intangibles and Goodwill Impairment, New York State Society of CPAs, November 9, 2002.

3. Bennett, C. and A. Bowles. Practical Steps toward Due Diligence, Journal of Environmental Health. 1994, 57(5), $21-24$.

4. Dahl, D. Conduct Due Diligence, INC, 2004, 26(10), 102 - 108

5. $\quad$ Greengard, S. Due Diligence: The Devil in the Details, Workforce, 1999, 78(10), 68 -73.

6. Feldman, S., Sullivan, T., and Winsby, R. (2003). What Every Business Owner Should Know About Valuing Their Business. New York: McGraw-Hill.

7. Fernandez, D Top 10 Most Common Intellectual Property Rights Mistakes during Venture Capital Due Diligence, Asia Pacific Biotech News, 2003, 17 (13) 768 - 770.

8. $\quad$ Fraser, J. A To-Do List for Due Diligence, INC, 1996, 18(2), 100 - 104.

9. Fulton, M. Due Diligence on Key Vendors: Looking for Floes in All the Right Places, Searcher, 2003, 11(8), $25-26$.

10. Goldman, K. (2005) Doing Due Diligence! Vetting the Vendors, Health Promotion Practices, 2005, 6 (4), $360-362$.

11. Kessenides, D. Buyer Beware, INC, 2004, 26(13), 48 - 57.

12. Loomer, S. and Harrington, A. Sharing Synergies, camagazine.com, May 2003.

13. McKinsey \& Co., Copeland, T., Koller, T., and Murrin, J. (2000). Valuation: Measuring and Managing the Value of Companies, 3rd ed. New York: John Wiley \& Sons.

14. Melles, J. How Do You Buy a Small Business? Laser Focus World, 1996 32(5), 59 - 60.

15. Oakes, K. Do the Due Diligence, $T+D$, (58(4), $15-16$.

16. Palapu, K., Healy, P., and Bernard, V. (2004). Business Analysis \& Valuation: Using Financial Statements, $3^{\text {rd }}$ ed. Mason, $\mathrm{OH}$ : Thompson South-Western.

17. Pallarito, K. Deals Often Require Detective Work, Modern Healthcare. 1995, 25(37) 54.

18. Power, H. Takeover Panel: Sort Out Pensions before Going Hostile, Lawyer, 2005, 19 (19), 1 - 4.

19. Preston, R. The Trouble with Mergers, Network Computing. 2005 16(4), 6.

20. Rivas, T. Due Diligence in IP, Managing Intellectual Property, 2002, 116, 68 - 71.

21. Tabon, N. The Importance of Due Diligence, Managing Intellectual Property. 2002 116, 68 -71. 


\section{NOTES}

